\title{
THE ANNUAL MEETING OF THE SOCIETY
}

The fifty-first Annual Meeting of the American Mathematical Society was held at the Museum of Science and Industry, Chicago, Illinois, Friday and Saturday, November 24 and 25, 1944, in conjunction with meetings of the Mathematical Association of America. Over two hundred persons registered, including the following one hundred seventy-seven members of the Society:

V. W. Adkisson, A. A. Albert, Warren Ambrose, B. M. Armstrong, W. A. Asprey, Max Astrachan, Reinhold Baer, R. M. Ballard, R. H. Bardell, Walter Bartky, Felix Bernstein, H. R. Beveridge, S. F. Bibb, H. L. Black, G. A. Bliss, Henry Blumberg, D. G. Bourgin, M. G. Boyce, A. J. Brandt, R. W. Brink, R. H. Bruck, E. L. Buell, R. S. Burington, Herbert Busemann, W. H. Bussey, Albert Cahn, W. D. Cairns, W. B. Carver, W. B. Caton, Subrahmanyan Chandrasekhar, J. H. Chanler, E. W. Chittenden, R. V. Churchill, M. D. Clement, R. H. Cole, J. J. Corliss, D. R. Curtiss, Paul D'Arco, J. Edgar Davis, John DeCicco, M. W. Dehn, Douglas Derry, Paul Eberhart, Paul Erdös, H. P. Evans, H. S. Everett, Will Feller, J. V. Finch, N. J. Fine, L. R. Ford, R. H. Fox, J. S. Frame, Evelyn Frank, R. E. Fullerton, H. M. Gehman, J. W. Givens, G. D. Gore, L. M. Graves, L. W. Griffiths, V. G. Grove, P. E. Guenther, D. W. Hall, P. R. Halmos, R. W. Hamming, W. L. Hart, J. O. Hassler, E. D. Hellinger, Fritz Herzog, E. H. C. Hildebrandt, T. H. Hildebrandt, J. D. Hill, D. L. Holl; T. R. Hollcroft, S. P. Hughart, H. K. Hughes, C. C. Hurd, M. H. Ingraham, R. D. James, Karl Johannes, A. W. Jones, B. W. Jones, William Karush, D. E. Kearney, I. F. Keeler, H. R. Kingston, J. R. Kline, L. A. Knowler, J. C. Koken, W. C. Krathwohl, Joseph Landin, E. P. Lane, R. E. Langer, E. H. Larguier, D. H. Leavens, B. A. Lengyel, A. L. Lewis, A. T. Lonseth, C. C. MacDuffee, H. F. MacNeish, Murray Mannos, Morris Marden, A. V. Martin, R. M. Martin, W. T. Martin, J. R. Mayor, Karl Menger, A. N. Milgram, H. J. Miser, W. L. Miser, A. C. Moeller, J. T. Moore, C. W. Moran, E. M. Morenus, E. J. Moulton, F. H. Murray, J. R. Musselman, A. L. Nelson, John von Neumann, C. V. Newsom, Ivan Niven, E. P. Northrop, F. S. Nowlan, E. B. Ogden, Rufus Oldenburger, J. M. H. Olmsted, F. W. Owens, Gordon Pall, P. M. Pepper, George Piranian, J. C. Polley, J. F. Randolph, R. B. Rasmusen, W. T. Reid, Haim Reingold, P. R. Rider, L. V. Robinson, W. H. Roever, A. E. Ross, E. H. Rothe, Arthur Saastad, Hans Samelson, R. G. Sanger, O. F. G. Schilling, K. C. Schraut, G. E. Schweigert, I. E. Segal, M. E. Shanks, H. A. Simmons, R. C. Simpson, E. R. Smith, G. W. Smith, W. S. Snyder, R. C. Stephens, B. M. Stewart, E. B. Stouffer, E. G. Swafford, H. P. Thielman, T. Y. Thomas, C. J. Thorne, W. J. Trjitzinsky, Henry Van Engen, J. I. Vass, W. A. Vezeau, H. S. Wall, M. J. Weiss, E. L. Welker, P. A. White, G. W. Whitehead, W. M. Whyburn, L. R. Wilcox, J. E. Wilkins, K. P. Williams, R. S. Wolfe, M. A. Wurster, Oscar Zariski, M. C. Zeller, H. J. Zimmerberg.

Sessions for the reading of contributed papers were held Friday at 2:00 P.M., Saturday at 10:45 A.M. and 3:15 P.M. The presiding officers for these sessions were Dean E. B. Stouffer, Professor E. W. Chittenden and Professor Karl Menger.

The eighteenth Josiah Willard Gibbs Lecture was given Friday 
evening by Professor John von Neumann on The ergodic theorem and statistical mechanics. Vice President L. M. Graves presided. The attendance was about three hundred.

The annual business meeting and election of officers was held on Saturday morning, Vice President Graves presiding. The proceedings are included later in the report. At the close of the business session, Vice President Graves announced the award of the Cole Prize in Algebra to Professor Oscar Zariski of the Johns Hopkins University for the following series of memoirs: (a) Some results in the arithmetic theory of algebraic varieties, Amer. J. Math. vol. 61 (1939) pp. 249294; (b) Algebraic varieties over ground fields of characteristic zero, Amer. J. Math. vol. 62 (1940) pp. 187-221; (c) The reduction of the singularities of an algebraic surface, Ann. of Math. vol. 40 (1939) pp. 639-689; (d) Local uniformization on algebraic varieties, Ann. of Math. vol. 41 (1940) pp. 852-896. Professor Zariski gave a brief résumé of these memoirs.

Saturday afternoon with Professor John von Neumann presiding, Professor Will Feller of Brown University gave an address entitled Limit theorems in the theory of probability.

Sessions of the Mathematical Association of America were held on Saturday evening and Sunday morning.

There was a dinner Saturday evening at Hotel Windermere West for mathematicians and their guests. The toastmaster was President W. M. Whyburn of Texas Technological Institute. Professor R. E.. Langer of the University of Wisconsin spoke on some problems which may be expected to confront mathematicians in the postwar period, and dwelt briefly upon the great loss sustained by mathematics and by the members of this Society in the recent death of Professor G. D. Birkhoff. Professor W. T. Martin of Syracuse University presented resolutions expressing the thanks and appreciation of the members of the Society and the Association to the local committee, the staffs of the Museum of Science and Industry and of the Hotel Windermere for the excellent arrangements.

At the meeting of the Board of Trustees at 6:00 P.M., November 24, 1944 , in the Hotel Windermere East, there was no quorum present and the Board adjourned to January 6, 1945. The Council met at 9:00 P.M. on November 24, 1944, in the Hotel Windermere East.

The Secretary announced the election of the following nineteen persons to membership in the Society (the address given is that of the member at the time of his application):

Mr. Harold William Becker, Mare Island Navy Yard, Calif.;

Dr. Donald Lee Benedict, Sylvania Electric Products, Inc., Flushing, N. Y.; 
Miss Grace L. Bolton, New Jersey College for Women;

Lieutenant Paul Francis Byrd, Army Air Corps;

Mr. Frederick Merle Carpenter, Missouri School of Mines;

Mr. Jasper Brown Jeffries, Metallurgical Laboratory, University of Chicago;

Dr. Herbert Jehle, Harvard University;

Mr. Richard Eugene Krug, Milwaukee Public Library;

Dr. Vincent Owen McBrien, College of the Holy Cross;

Dr. Donald Curtis May, Jr., Bureau of Ordnance, Navy Department;

Lieutenant Edwin Evariste Moise, U.S.N.R., Naval Communications Annex, Washington, D. C.;

Mr. Philip Peak, University School, Indiana University;

Dr. Robert Collom Rand, U.S.N.R.;

Mr. Shien-Siu Shü, School of Mechanics, Brown University;

Professor Allen Simmons, Bethany College, Bethany, W. Va.;

Dr. Karl H. Stahl, State Teachers College, California, Pa.;

Dr. Paul Porter Sutton, Geophysical Laboratory, Carnegie Institution of Washington;

Mr. Henry Zatzkis, University of North Carolina.

It was reported that the following had been elected as nominees on the Institutional Memberships of the institutions indicated:

Columbia University: Mr. Aaron Galuten, Professors Sigfrido Carlos Mazza and Milton da Silva Rodrigues, Mr. Hing Tong;

University of Pennsylvania: Mr. Charles W. Saalfrank;

University of Washington: Mr. Marvin Clifford Stippes.

The following appointments by President M. H. Stone were reported: as representative of the Society at the inauguration of W. M. Whyburn as President of Texas Technological College on September 30, 1944, Professor H. J. Ettlinger; as representative of the Society at the inauguration of Homer Levi Dodge as President of Norwich University on October 9, 1944, Dean Elijah Swift; as representative of the Society at the inauguration of Howard Foster Lowry as President of The College of Wooster on October 21, 1944, Professor C. O. Williamson; as tellers for the election at the 1944 Annual Meeting, Professor W. C. Krathwohl, Drs. Mary E. Ladue and W. C. Strodt; as a member of the committee to study the role of the Society in the publication of mathematical research (replacing Professor A. E. Taylor), Professor G. C. Evans; as a member of the Committee on Printing Contracts for the period 1945-1947, Professor R. M. Foster (committee now consists of Professor R, M. Foster, Dean M. H. Ingraham, and Professor J. D. Tamarkin); as a member of the Committee on Places of Meetings for the period 1945-1947, Professor W. T. Reid (committee now consists of Professors W. B. Carver, Chairman, C. R. Adams, and W. T. Reid); as new members of the Committees to Select Hour Speakers: for Annual and Summer Meetings, Professor C. C. MacDuffee (committee now consists of Profes- 
sors J. R. Kline, Chairman, C. C. MacDuffee, and J. D. Tamarkin); for Eastern Sectional Meetings, Professor Oystein Ore (committee now consists of Professors T. R. Hollcroft, Chairman, E. J. McShane, and Oystein Ore); for Western Sectional Meetings, Professor Tibor Radó (committee now consists of Professors R. H. Bruck, Chairman, A. A. Albert, and Tibor Radó); for Far Western Sectional Meetings, Professor D. H. Lehmer (the complete membership of this committee will be announced later).

Certain invitations to give hour addresses were announced: Professor S. S. Chern for the February, 1945, meeting in New York City; Professors A. P. Morse and Witold Hurewicz for the April, 1945, meeting in New York City.

The Council voted to invite Professor Enrico Fermi to deliver the nineteenth Josiah Willard Gibbs Lecture at the 1945 Annual Meeting.

The Secretary reported that the ordinary membership in the Society is now 2,754, including 210 nominees of institutional members and 64 life members. There are also 86 institutional members. The total attendance at all meetings in 1944 was 1,126; the number of papers read was 284; there were 14 hour addresses, 2 symposium addresses, 1 Gibbs Lecture, and four Colloquium Lectures; the number of members attending at least one meeting was 714. The Secretary also reported that an effort had been made to increase the membership through the cooperation of chairmen of departments of mathematics.

At the annual election which closed on November 25, and at which 578 votes were cast, the following officers were elected:

President, Professor T. H. Hildebrandt.

Vice President, Professor J. M. Thomas.

Secretary, Professor J. R. Kline.

Associate Secretary, Professor T. R. Hollcroft.

Treasurer, Professor B. P. Gill.

Librarian, Professor Arnold Dresden.

Members of the Editorial Committee of the Bulletin, Professor Saunders MacLane and Dean E. B. Stouffer.

Member of the Editorial Committee of the Transactions, Professor Oscar Zariski.

Member of the Editorial Committee of the Colloquium Publications, Professor C. C. MacDuffee.

Member of the Editorial Committee of Mathematical Reviews, Professor Oswald Veblen.

Members of the Editorial Committee of Mathematical Surveys, Professors A. A. Albert, Nelson Dunford, and J. D. Tamarkin. 
Member of the Editorial Committee of the American Journal of Mathematics, Professor Richard Brauer.

Members at large of the Council, Professors H. F. Bohnenblust, S. S. Cairns, H. B. Curry, M. H. Ingraham, I. S. Sokolnikoff.

Members of the Board of Trustees, Professors W. R. Longley, Marston Morse, G. W. Mullins, Dean R. G. D. Richardson, and Dr. Warren Weaver.

Professor Hermann Weyl was appointed as a member of the Editorial Committee of the American Journal of Mathematics, to fill the unexpired term of Professor G. D. Birkhoff.

The Council adopted the following resolution on the death of Professor G. D. Birkhoff:

On November 12,1944, this Society lost through death an illustrious and distinguished leader-a widely known and esteemed member-George David Birkhoff. Professor Birkhoff was in the sixty-first year of his life. He was in possession of his full mental vigor, and to outward appearances of his whole physical strength as well. The news of his death, therefore, came to many of his friends unexpectedly and unmitigated in its suddenness.

From the time of his early manhood to that of his end Professor Birkhoff was a force in American mathematics, and only less directly so in the wider realm of general American scholarship. Intellectually he was alert, active and versatile; as a mathematician he was peculiarly original and profound. His researches, which were numerous and prolific of important results, in many instances blazed the ways in which other investigators have found it fruitful to follow. At their best they sufficed at times to encompass difficulties the resolution of which served to open, or to reopen afresh, important channels of mathematical development. In their broader aspects the works of Professor Birkhoff have become widely known. In their details an enumeration of them would be lengthy and impressive. The whole measure of the man, however, would reach beyond the bounds of any such listing, complete though the catalogue might be.

Professor Birkhoff's personality was vigorous and dynamic. Over a period of almost forty years he graced the meetings and journals of this Society with the presentations and publications of his results. He entered actively into the discussions of this Council, officiated as editor of the Transactions, and participated in the work and deliberations of many committees. He was the Society's president in 1925 and 1926.

Professor Birkhoff was a distinguished teacher, extraordinarily gifted for the guidance of advanced students and particularly of those who came to him for training for mathematical research. Such students found him admirably accessible intellectually, and profited greatly from his faculty for the sensing and definition of problems which were at once significant and yet within a modest technical reach. He gave willingly of his time and counsel, and seemed able to impart without effort his own enthusiasms and his own high critical standards. Many members of this Society have had such contacts with him. Many in a sense look upon him, therefore, as the master, with an almost filial regard.

Professor Birkhoff's quality as a scholar was widely recognized. A number of important prizes were won by him, among them the Bocher Prize of this Society. His name appears on the rolls of the National and American Academies and upon that of the American Philosophical Society. The American Association for the Advancement 
of Science bestowed its annual prize upon him in 1926 and elevated him to its presidency in 1937. More than a dozen universities, over half of them in foreign lands, conferred the honorary doctorate upon him, and no less than half a score of foreign mathematical societies extended their fellowship or honorary membership to him. It seems almost fair to say that Professor Birkhoff had come to be looked upon in this country and abroad as the symbol of the stature of American mathematics.

With Mrs. Birkhoff, who by her graciousness and charm has endeared herself widely among its membership, this Society grieves the departure of Professor Birkhoff. In the richness of his influence and in the wealth of his accomplishments, however, it takes pride and finds the deepest satisfaction.

This resolution was read at the annual business meeting and the members of the Society stood for a minute in respect to the memory of their distinguished colleague. The Council requested the incoming president to appoint a committee to study the problem of a suitable memorial for Professor Birkhoff.

The Council voted to hold the 1945 Summer Meeting June 24-25 in Montreal, Canada, at the conclusion of the Canadian Mathematical Congress. The invitation to meet at Macdonald College of McGill University was accepted with the appreciation of the Council.

Since the 1944 Annual Meeting was held before the close of the Society's fiscal year, it was impossible to present a full report of the Treasurer. (Excerpts of the final report of the Treasurer, however, appear on pages 35-38 of this Bulletin.) It was reported: (1) That total receipts would exceed estimates by considerable amounts. This is due to the fact that more than 150 ordinary members have been added during the year, the amount from contributing memberships has increased, all institutional memberships have been continued, and subscription lists for the Society's periodicals have grown. (2) That total disbursements would be within expectations and the actual excess of receipts over expenditures would be a considerable amount. The surplus which has been thus created will be needed to meet the difficult financial situation which will probably confront the Society in the years immediately following the war.

The Librarian reported the following additions to the Library: 28 books, 58 bound volumes of periodicals, 306 printed dissertations, 136 dissertations on microfilm. He also reported that 90 members of the Society have used the library during the academic year 19431944.

The Bulletin Editorial Committee reported that it would publish approximately 1,000 pages in 1944 . The Committee is able to publish a research paper with reasonable promptness after it is received from the author whereas a few years ago a year or more elapsed between the receipt of the paper and the time of publication. The editors re- 
gard the present accelerated publication as highly desirable and are making plans to maintain it. The Editorial Committee is no longer adhering to the limitation of ten or fewer pages for papers to be published in the Bulletin. It was reported that Professors R. H. Bruck, R. H. Cameron, Irving Kaplansky, J. C. Oxtoby, and Leo Zippin have been appointed as Assistant Editors, to replace Professors P. O. Bell, O. F. G. Schilling, Garrett Birkhoff, W. B. Carver, Morris Marden, and Virgil Snyder.

The Transactions Editorial Committee reported that it would publish approximately 1,100 pages during 1944 . The backlog of papers continues low and manuscripts are published within six or eight months after receipt.

The Mathematical Reviews Editorial Committee reported that abstracts of mathematical literature have been published in the usual form despite the continued difficulties ensuing from the war. The situation regarding foreign literature has been somewhat alleviated and the coverage of the mathematical literature of the world is practically complete with the exception of certain journals from Italy. The editors feel that this situation will be relieved shortly. During the year the Edinburgh Mathematical Society has been added to the list of sponsors of Mathematical Reviews. The total number of subscriptions is at present 1,332 , while the financial situation continues to develop favorably.

On recommendation of the Colloquium Editorial Committee, the Council voted to invite Professor Hassler Whitney to deliver the Colloquium Lectures at the 1946 Summer Meeting.

The War Policy Committee reported concerning its activities since the last meeting of the Council: (1) The subcommittee appointed to advise the Examinations Staff of the Armed Forces Institute (Professors W. T. Reid, Chairman, Ralph Beatley, L. L. Dines, W. L. Hart, C. C. MacDuffee) has completed examinations in trigonometry, analysis, geometry, college algebra, differential and integral calculus, which will be submitted to the Institute for accreditation purposes. The work of this subcommittee should prove of aid to college authorities in assigning college credit for work taken under the auspices of the Institute. (2) Chairman Stone has appointed a subcommittee on historical records of mathematicians in war activities consisting of the following: Professors J. R. Kline (temporary chairman), R. C. Archibald, Marston Morse. This committee is empowered to add to its membership. (3) The Office of Scientific Personnel is continuing its activities in the matter of placement of scientists in various phases of the war effort. This Office is now in a transition period and in the 
near future its work will be mostly concerned with the problem of postwar placement. The War Policy Committee has voted to continue to support the Office of which Dr. M. H. Trytten is now the Director. (4) The War Policy Committee is also studying the tremendous problem which will be created by the shortage of scientific personnel which is the result of the decrease in the number of graduate students during the war.

The resignations of Professors G. B. Price and A. D. Michal as Associate Secretaries were accepted. (Professor R. H. Bruck was subsequently elected by the Council, with the Board of Trustees approval, to fill the unexpired term of Professor Price.)

Titles and cross references to papers read at the meeting follow below. Papers 1 to 6 were read Friday afternoon, papers 7 to 11 Saturday morning, papers 12 to 16 Saturday afternoon, and papers 17 to 38 , whose abstract numbers are followed by the letter $t$, were read by title. Mr. C. C. Hsiung was introduced by Professor T. R. Hollcroft, Mr. Walter Kohn by Professor Alexander Weinstein, and Mr. C. T. Loo by Professor E. J. McShane.

1. W. H. Roever: Second derivatives of the potential function of the earth's weight field of force. (Abstract 51-1-33.)

2. V. G. Grove: Quadrics associated with a curve on a surface. (Abstract 51-1-39.)

3. W. J. Trjitzinsky: Singular integral equations with Cauchy kernels. (Abstract 51-1-22.)

4. W. S. Snyder: Derivatives of set functions. (Abstract 51-1-21.)

5. P. R. Halmos: On an incompressible transformation. (Abstract 51-1-36.)

6. A. T. Lonseth: Error-limitation for the method of least squares. (Abstract 51-1-46.)

7. R. H. Bruck: Quasigroup theory. II. The lower central series. Preliminary report. (Abstract 50-11-261.)

8. R. E. Fullerton: Linear operators with range in a space of differentiable functions. (Abstract 51-1-14.)

9. H.S. Wall: The convergence of a positive definite J-fraction in the limit-circle case. (Abstract 50-9-228.)

10. R. H. Fox: On topologies for function spaces. (Abstract 51-150.)

11. Felix Bernstein: The swastika and the Sicilian triskelon from the standpoint of "higher geometry." (Abstract 51-1-37.)

12. H. K. Hughes: The asymptotic developments of a class of entire functions. (Abstract 51-1-16.) 
13. T. R. Hollcroft: The probability of repetitions. (Abstract 51-143.)

14. W. T. Reid: A matrix differential equation of Riccati type. (Abstract 51-1-19.)

15. P. A. White: On regular transformations. (Abstract 50-11-287.)

16. N. J. Fine: Congruence properties of the elementary symmetric functions. (Abstract 51-1-6.)

17. R. P. Agnew: $A$ simple and natural notation for the theory of summability of series and sequences. (Abstract 50-11-268-t.)

18. R. P. Agnew: Spans in Lebesgue and uniform spaces of translations of step functions. (Abstract 50-11-269-t.)

19. E. F. Beckenbach: Concerning the definition of harmonic functions. (Abstract 50-11-270-t.)

20. L. M. Blumenthal: Generalized elliptic spaces and quadratic forms. (Abstract 51-1-48-t.)

21. R. H. Bruck: Quasigroup theory. III. Finite p-loops. Preliminary report. (Abstract 50-11-262-t.)

22. R. H. Bruck: Quasigroup theory. IV. Associatral series. Preliminary report. (Abstract 51-1-3-t.)

23. C. J. Everett: The basis theorem for vector spaces over rings. (Abstract 51-1-4-t.)

24. C. J. Everett and S. M. Ulam: Projective algebra. I. (Abstract 51-1-5-t.)

25. H. W. Eves: A geometrical note on the isocenter. (Abstract 51-1-25-t.)

26. C. C. Hsiung: A ternary of plane curvilinear elements with a common singular point. (Abstract 51-1-40-t.)

27. Fred Kiokemeister: The Asano postulates for orders in a linear algebra. (Abstract 51-1-10-t.)

28. Fred Kiokemeister and G. W. Whitehead: $A$ coset theory for left loops. (Abstract 51-1-11-t.)

29. Walter Kohn: Contour integration in the theory of the spherical pendulum and the heavy symmetrical top. (Abstract 51-1-27-t.)

30. A. T. Lonseth: $A$ note on relative errors in systems of linear equations. (Abstract 51-1-45-t.)

31. C. T. Loo: Note on the strong summability of Fourier series. (Abstract 51-1-17-t.)

32. C. T. Loo: Two Tauberian theorems in the theory of Fourier series. (Abstract 51-1-18-t.)

33. A. N. Lowan and H. E. Salzer: Formulas for inverse interpolation within a square grid in the complex plane. (Abstract 51-1-28-t.) 
34. Isaac Opatowski: A botanical application of Jensen's inequality. (Abstract 51-1-31-t.)

35. Ida Roettinger: An operational approach to the solution of boundary value problems by generalized Fourier series. (Abstract 51-1-32-t.)

36. A. R. Schweitzer: Functional relations valid in the domains of abstract groups and Grassmann's space analysis. II. (Abstract 51-120-t.)

37. Seymour Sherman: Complex polynomials and polygonal domains. (Abstract 51-1-12-t.)

38. Antoni Zygmund: On smooth functions. (Abstract 51-1-23-t.)

T. R. HOLLCROFT,

Associate Secretary 


\section{APPENDIX}

\section{EXCERPTS FROM REPORT OF TREASURER}

To the Board of Trustees of the

December 8, 1944

\section{American Mathematical Society}

Gentlemen:

I have the honor to submit herewith the report of the Treasurer for the fiscal year ended November 30, 1944. The following comments may be of interest.

\section{Investment Portfolio}

On November 30, 1944, the market value of securities held for Invested Funds exceeded book value by $\$ 3,566$, and the market value of securities held for Current Funds exceeded book value by $\$ 482$. In view of these figures and of the conservative character of many of the securities, the reserves held in accounts "Reserve for Investment Losses" and "Profit on Sales of Securities" may be considered sufficient protection against contingent depreciation in market value.

The investment portfolio now includes government bonds 29 per cent, other bonds 20 per cent, preferred stock 14 per cent, common stock 30 per cent, cash in savings banks 7 per cent.

\section{Income from Investments}

Income received during the year from investments of Current Funds amounted to $\$ 962$ exclusive of $\$ 87$ earmarked for International Congress. This represents a return of 2.1 per cent computed on average book value of investments. Income on Invested Funds amounted to $\$ 6,851$ representing a return of approximately $3 \frac{2}{3}$ per cent. Total investment income from all sources was thus $\$ 7,900$ representing a return somewhat under $3 \frac{1}{3}$ per cent. These rates of return are slightly under the corresponding rates for the fiscal year 1943 as the result of purchases of additional government bonds.

Income from the Henderson Estate was $\$ 4,511$, which is slightly more than was received in 1943 from this source.

\section{Increase in Surplus and Assets}

Surplus account shows an increase of $\$ 9,212$ after transferring $\$ 5,463$ from Surplus to Endowment Fund Principal. This excellent outcome of the operations for the year is to be attributed among 
other things to a gain of some 150 ordinary memberships, a gain of $\$ 100$ in contributing memberships, larger subscription lists for all of the Society's periodicals supported from general receipts, and unexpectedly heavy sales of back volumes. It is to be discounted a little by the fact that payment for the List of Members now in the course of publication will be deferred to the next fiscal year.

Further light on the results of the year's financial operations is given by noting that total assets increased during the year by $\$ 23,637$ so that their amount is now $\$ 258,209$. This increase reflects, in addition to the above mentioned increase in surplus, a gain in subscriptions to and in back volume sales of Mathematical Reviews, the fact that no provision had to be made for printing new volumes either of the Colloquium Series or of Mathematical Surveys, and the accumulation of income in the special funds held by the Society. The assets include $\$ 1,719$ of a grant from the Rockefeller Foundation held for the use of the War Policy Committee.

Respectfully submitted, Bennington P. Gill, Treasurer 
BALANCE SHEET

Assets

CurRent Funds:

November November

$30,1944 \quad 30,1943$

Cash................................. \$27,973.79

Investments.

$41,839.37$

$19,846.11$

$36,731.06$

$\$ 69,813.16$

$\$ 56,577.17$

INVESTED FUNDS:

Cash..............................

Investments.

$\$ 336.09$ $188,059.77$

$\$ 1,273.67$

$\$ 188,395.86$

$176,721.29$

$\$ 177,994.96$

Total Assets

$\$ 258,209.02$

$\$ 234,572.13$

CURRent Funds:

Liabilities

Mathematical Reviews....................

Colloquium............................

Mathematical Surveys...................

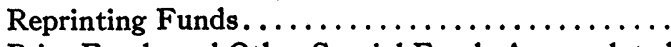

Prize Funds and Other Special Funds Accumulated

Income..............................

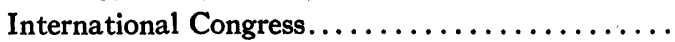

War Policy Committee.....................

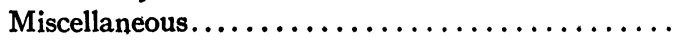

Sinking Fund.$\ldots \ldots \ldots \ldots \ldots \ldots \ldots \ldots \ldots$

Profit on Sales of Securities..................

Surplus.......................... $32,967.13$

$11,936.09$

$7,368.15$

$1,236.10$

$3,765.26$

$\$ 14,252.62$

$5,761.69$

840.03

$2,239.10$

$3,332.75$

$6,233.39$

$1,719.41$

72.56

768.96

413.36

$2,296.18$

$6,146.06$

$\$ 69,813.16$

80.99

592.34

612.86

$23,755.30$

$56,577.17$

\section{INVESTED FUNDS:}

Endowment Fund Principal

$\$ 65,573.18$

$31,033.22$

Prize Funds and Other Special Funds..........

$4,032.68$

Life Membership and Subscription Reserve......

Colloquium.............................

Mathematical Reviews.

$5,000.00$

$65,000.00$

$4,385.89$

$\frac{13,370.89}{\$ 188,395.86}$

Profit on Sales of Securities.

$\$ 60,110.68$

$31,033.22$

$4,434.81$

$5,000.00$

$60,000.00$

$4,385.89$

$13,030.36$

$188,395.86$

$\$ 177,994.96$

Total Liabilities. . . . . . . . . . . . $\$ 258,209.02$

$\$ 234,572.13$ 


\section{SUMMARY STATEMENT OF INCOME AND EXPENDITURES}

1943-1944

\begin{tabular}{|c|c|c|c|c|}
\hline & \multicolumn{2}{|c|}{1944} & \multicolumn{2}{|c|}{1943} \\
\hline & Receipts & $\begin{array}{c}\text { Disburse- } \\
\text { ments }\end{array}$ & Receipts & $\begin{array}{c}\text { Disburse } \\
\text { ments }\end{array}$ \\
\hline \multicolumn{5}{|l|}{ ENERAL RECEIPTS: } \\
\hline \multirow{6}{*}{ 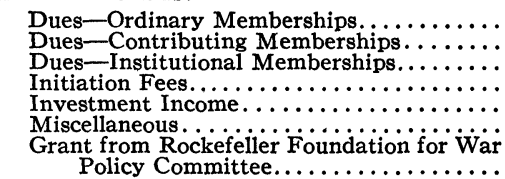 } & $\$ 18,060.64$ & & $\begin{array}{r}\$ 16,514.71 \\
859.63\end{array}$ & \\
\hline & $7,510.02$ & & $6,616.52$ & \\
\hline & 793.95 & & 378.84 & \\
\hline & $8,836.16$ & & $8,612.83$ & \\
\hline & & & & \\
\hline & $3,750.00$ & & $1,250.00$ & \\
\hline
\end{tabular}

GENERAL DISBURSEMENTS:

Secretaries.

Treasurer.$\ldots \ldots \ldots \ldots \ldots \ldots \ldots \ldots$

Officers' Traveling $\ldots \ldots \ldots \ldots \ldots \ldots \ldots \ldots$

Officers Travelin

Library $\ldots \ldots \ldots \ldots \ldots \ldots \ldots \ldots \ldots \ldots$

War Policy Committee Expenses.........

Emergency...........................

Total.

$\$ 40,252.67 \quad \$ 10,486.91$

Excess of General Receipts.

$\$ 5,642.71$

$1,070.77$

600.00

984.46

$2,030: 59$

158.38

\section{$\$ 29,765.76$}

$\$ 5,590.02$

$1,093.58$

581.23

893.15

$\mathbf{1 , 5 8 4 . 1 7}$

4.90

$\$ 34,272.49 \$ 9,747.05$

$\$ 24,525.44$

Publication:

Bulletin

$\$ 2,462.10$

$\$ 11,189.68$

$\$ 1,710.80$

$\$ 11,536.88$

Bulletin Reprinting. . . . . . . . . . . . . .

Transactions

856.40

$7,097.63$

669.76

Colloquium

$8,644.20$

$5,886.83$

$8,309.42$

$1,603.62 \quad 3,951.38$

$3,210.08$

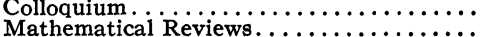

Mathematical Survey's.

$15,453.49$ $3,951.38$

$10,235.88$ 317.75 180.65

4.03

$3,600.89$

994.73

Semicentennial Publications...................

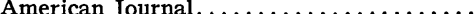

Total.

$\$ 30,643.93 \$ 37,029.30$

76.35

$12,167.95$
$2,760.86$

$2,500.00$

$\$ 27,261.24 \quad \$ 39,159.00$

Excess Cost of Publication..........

$\$ 6,385.37$

$\$ 11,897.76$

OTHER:

Special Funds (including Congress) .........

$\$ 1,223.90 \$ 100.00$ 141.03

Gift from R. C. Archibald ..................

Miscellaneous. . ......................

From Surplus:

Transactions Reprinting..$\ldots \ldots \ldots \ldots$

Mathematical Reviews................

Total.

$\ldots \ldots \ldots \ldots$

Difference.

$\$ 1,364.93 \$ 1,108.43$

$\$ 256.50$

8.43

$\$ 1,273.41 \$ 3,600.00$ $9,160.49$

80.97

12.03

750.00

300.00

$1,000.00$

Net Change in Assets.

$\$ 23,636.89$

$1,000.00$

$\$ 10,433.90 \$ 5,743.00$

$\$ 4,690.90$

$\$ 17,318.58$

$\$ 217,253.55$

ASSETS BEgINNING OF YeAR .

$\$ 234,572.13$

$\$ 234,572.13$ 